\title{
Dr. Mailoo Visuvaratnam - Consultant Physician
}

Mailoo Visuvaratnam was born in Jaffna on 7 February 1931. He was a student at St John's College, Jaffna and then at Royal College, Colombo from where he entered Medical College. Throughout his academic career he was a brilliant student, winning many awards and scholarships. All this he took in his stride. He was selfeffacing about his work and achievements in medicine. Visva qualified as a doctor in 1954 and received his Doctorate in Medicine in 1958. Thereafter he proceeded to London and gained the MRCP diploma with the greatest of ease.

On his return to Sri Lanka he served as a Consultant Physician in Batticaloa, Kurunegala, Jaffna and Kandy. Visva was a masterly teacher. He taught students the common sense approach to difficult medical problems and to think with clarity and precision. He encouraged doctors to show their patients kindness and sympathy that he himself showed in his long and illustrious career. His clinical acumen and skills are legendary and have passed into medical folklore among his numerous students who have had the good fortune to work with him. His presence made a difference to the many who worked in hospital and to those who received his care. He brought to his work an uncommon sympathy and a marked individualism which was reinforced by his Hindu faith.

I was his neighbour in Kurunegala as a junior doctor. Those were difficult times and my life was then in turmoil. Visva and his wife Thana helped me to maintain my sanity and to tide over the most stressful time of my life. I remember fondly their words of advice and encouragement. He was never less than professional, and knew how to unravel a complex situation and arrive at a helpful compromise. Although I kept in touch with him from time to time I regret very much not seeing him before his departure from this world. For in our sojourn through life we rarely meet such great men.

His erudite career in medicine in Sri Lanka was cut short by the ethnic strife of 1983 . Thereafter, he emigrated to the UK and settled in St Albans, where he continued his work in Hertfordshire. I saw him on his arrival in UK. Although sad to leave Sri Lanka he was philosophical. Despite the setback he remained a respected friend, and a fine physician to many. He never wavered in his love for his native country. Visva was admired and loved by his numerous friends, colleagues and patients.

On retirement he took time to admire the beauty of nature and spend quality time with his close family and friends. He kept his brain cells in good trim playing contract bridge and Sudoku.

He was generous and possessed deep powers of sympathy and understanding. He saved my life from certain ruin. To his wife Thana and their daughter Kumi he was an inspiration, a tower of strength and simply irreplaceable.

His end on 17 April 2007 was swift and peaceful. May he find lasting peace and happiness!

Nihal D Amerasekera, Consultant Radiologist.

E-mail <douglasamera@yahoo.com> 